\title{
Design and Evaluation of Tractor Operated Raised Bed Mechanical Carrot Planter
}

\author{
Shiddanagouda Yadachi $^{\text {** }}$ and Indra Mani ${ }^{2}$ \\ ${ }^{1}$ Division of Agricultural Engineering, College of Horticulture Engineering and Food \\ Technology, University of Horticultural Sciences, Bagalkot-587104, Karnataka, India \\ ${ }^{2}$ Division of Agricultural Engineering, IARI, New Delhi, India \\ *Corresponding author
}

\begin{tabular}{|l|}
\hline K e y w o r d s \\
$\begin{array}{l}\text { Mechanical carrot planter, } \\
\text { Biogas slurry, Thirame } \\
\text { coated, Quality feed } \\
\text { index, Germination }\end{array}$ \\
\hline Article Info \\
\hline $\begin{array}{l}\text { Accepted: } \\
16 \text { August } 2018 \\
\text { Available Online: } \\
\text { 10 September } 2018\end{array}$ \\
\hline
\end{tabular}

\section{A B S T R A C T}

Carrot (Daucus carota L.) is a major vegetable crop which is a good source for human diet. Carrot planting, conventionally done by manual dibbling, is a labour intensive and thus, costly operation. The mechanization of carrot planting aims to reduce the operational costs, minimizing human drudgery and enhance the production. The appropriate cropmachine and operational parameters were identified. Tractor operated prototype mechanical carrot planter was designed and evaluated for its field performance using treatments viz. uncoated carrot seeds $\left(S_{1}\right)$, biogas slurry coated seeds $\left(S_{2}\right)$ and Thirame coated seeds $\left(S_{3}\right)$. The average plant spacing was $(5.1 \mathrm{~cm})$ nearly equal to theoretical seed spacing of $5 \mathrm{~cm}$ for treatment $\mathrm{S}_{2}$. The best quality of planting was observed for treatment $S_{3}$ with quality of feed index of 82.86 per cent, followed by treatment $S_{2}$ (80 per cent) and $S_{1}$ uncoated seed (67.4 per cent). Lower miss and multiple indices were observed for treatment $S_{3}$ (8.57 per cent) followed by treatment $S_{2}\left(10.71\right.$ per cent) and $S_{1}(15.71$ per cent). The optimum plant population per meter length of bed was 72 for $S_{2}$ against theoretical plant population of 80 plants. Significantly higher carrot root dimensions such as length and diameter were recorded under treatment $S_{2}(21.92 \mathrm{~cm}$ and $3.37 \mathrm{~cm})$. The higher carrot yield of $20.14 \mathrm{t} \mathrm{ha}^{-1}$ was recorded under $S_{2}$ followed by $14.69 \mathrm{t} \mathrm{ha}^{-1}$ for $S_{1}$. The low cost of operation of Rs. $1441 \mathrm{ha}^{-1}$ was recorded for mechanical carrot planter. The minimum draft of $378 \mathrm{kgf}$ and fuel consumption of $4.2 \mathrm{lph}$ was recorded. The adoption of mechanical planter for planting carrot could help save cost of Rs.1059 ha ${ }^{-1}$ (53.88 per cent) in comparison to manual planting.

\section{Introduction}

Carrot (Daucus carota L.), is an important root vegetable crop grown over 150 countries throughout the world. In India, carrot is cultivated in an area of $0.86 \mathrm{~m}$ ha (NHB 201516) with a production potential of 13.5 million tons. Carrots are an excellent source of antioxidant compounds, and the richest vegetable source of the pro-vitamin A carotenes. Carrot's antioxidant compounds help protect against cardiovascular disease and cancer and also promote good vision, especially night vision. Low level of mechanization of carrot planting and harvesting is a major hindrance in increasing 
the production and productivity of carrot. Carrot sowing is traditionally done by broadcasting and manual dibbling in which carrot seed is placed at a depth of 2-3 cm with $15-20 \mathrm{~cm}$ row spacing. Since, it is a labour intensive and costly operation, precise planting requires proper seed placement in a row at desired depth and equal spacing. A proper planting saves seed, advantageous in utilising nutrients from soil, invites less competition between plants for nutrients and increase yield by enabling good cultivation practices. The uniform plant spacing and depth aids for further mechanization of intercultural operation that reduces total cost of cultivation (Bakhtiari and Loghavi, 2009). In precision belt carrot seeder So11 Alex best quality of carrot sowing was achieved at working speed of $0.7 \mathrm{~ms}^{-1}$ (Kowalczuk and Zarajczyk, 2006). At the speed of $1 \mathrm{~ms}^{-1}$ sowing quality slightly deteriorated, while at $1.4 \mathrm{~ms}^{-1}$ the achieved results in terms of singulation and per cent skips were significantly worse (Bracy et al., 1999). It has been reported that, in evaluation of a mechanical seed planter for transplanting elgrass seeds, the mean seedling establishment for mechanical seed planter was significantly greater than for broadcasted seeds (Robert et al., 2008). The use of belt type planter for planting cotton resulted in 68.62 per cent and 98.46 per cent saving in cost and time, respectively (Kamaraj and Kathirvel, 2008).

The mechanization of planting operation in carrot crop is negligible; however some seed drills have been adopted by the farmers in northern India (Haryana, Punjab). No mechanical system is available till date for planting of carrot. In view of above, the study was envisaged to design and evaluate the mechanical planter for carrots. The objective of this study was to design planter for planting carrot seeds on raised beds of height $20 \mathrm{~cm}$, top width of $35 \mathrm{~cm}$ and four rows on the bed at $7.5 \mathrm{~cm}$ interval.

\section{Materials and Methods}

The designed carrot planter consisted of main frame, seed hopper, inclined plate seed metering device, ground wheel, power transmission system, bed former, row marker, ridger-cum-furrow opener and seed covering device. Based on the physical and engineering properties of carrot seeds the design values for the different parts of the planter were finalized. To improve the carrots seeds linear dimensions and their singulation ability in seed metering mechanism, seeds were coated with biogas slurry and thirame fungicide (Fig. 1). The linear dimensions of the coated seeds and weight of seeds increased considerably (Shiddanagouda Yadachi et al., 20102). The seed coating enhances the seed germination, viability and emergence rate (Shiddanagouda Yadachi et al., 2014). The angle of repose for uncoated $\left(\mathrm{S}_{1}\right)$, slurry coated $\left(\mathrm{S}_{2}\right)$ and Thirame coated $\left(S_{3}\right)$ seeds were $35.3^{\circ}, 36.13^{\circ}$ and $36.46^{\circ}$, respectively (Shiddanagouda Yadachi et al., 2014). The hopper slope was thus decided at $40^{\circ}$ by considering standard deviation of 3.1 ofthe values of angle of repose of the seeds (Shiddanagouda Yadachi et al., 2013). The trapezoidal shape seed hopper was fabricated with the side wall slope of $40^{\circ}$ to the horizontal of size $165 \mathrm{~mm} \times 190$ $\mathrm{mm}$ and $130 \mathrm{~mm} \times 105 \mathrm{~mm}$ at the top and bottom, respectively. The $25 \mathrm{~mm}$ diameter nylon pipe was fitted to $25 \mathrm{~mm}$ mild steel pipe which carried the seeds from seed hopper to the slit opened in the soil. The ground wheel of diameter $500 \mathrm{~mm}$ was fabricated using 100 $\mathrm{mm}$ wide mild steel sheet. Fourteen numbers of lugs were provided at regular interval along the radius of the ground wheel. Lugs $(50 \mathrm{mmx} 100 \mathrm{~mm})$ were provided for reducing the slippage during the operation (Fig. 2).

The power transmission from the ground wheel to the inclined plate seed metering device was at two stages. The chain and sprocket was mounted at the front side of the 
main frame between the ground wheel and countershaft with suitable frameworks (Fig. $3)$. The reduction ratio of ground wheel and inclined seed metering device was 1.88: 1 . The mild steel pipes of $25 \mathrm{~mm}$ diameter with pointer at one end were welded to the rear edge of bed former at interval of $75 \mathrm{~mm}$ between them, which acted as row marker. Shoe type ridger cum furrow opener was fixed below the main frame to a length of $300 \mathrm{~mm}$. A semi-circular loop made of mild steel was provided at the rear and between the wings of furrow opener to cover the seeds with soil. The roller type seed covering device was fabricated using mild steel circular section of diameter $50 \mathrm{~mm}$ and width of $350 \mathrm{~mm}$. The main frame of the unit (1194mmx812mm) was fabricated using a mild steel square section of size $63.5 \mathrm{~mm} \times 63.5 \mathrm{~mm}$. The seed hopper and inclined plate seed metering device were mounted on the frame of angle iron of size (50mmx50mm). Three-point hitch assembly was provided at front of the main frame so as to hitch the unit to prime mover.

\section{Field evaluation of planter}

The prototype carrot planter was evaluated for its performance in sandy loam soil at Division of Agricultural Engineering, IARI, New Delhi. The planter was evaluated at forward speed of $1.5 \mathrm{kmph}$ at $12.3 \pm 0.2 \%$ (d.b) soil moisture content. The top and bottom width of bed were $350 \mathrm{~mm}$ and $700 \mathrm{~mm}$, respectively. The row and plant spacing on the bed adopted was $75 \mathrm{mmx} 50 \mathrm{~mm}$ for carrot.

\section{Results and Discussion}

The prototype planter was tested both in the laboratory and field. The planter was evaluated for three types of carrot seeds i.e., uncoated $\left(\mathrm{S}_{1}\right)$, biogas slurry coated $\left(\mathrm{S}_{2}\right)$ and Thirame coated $\left(\mathrm{S}_{3}\right)$. In laboratory the row to row variation in seeds metering and uniformity of seed delivery were studied. The results indicated that variation of seed discharged from the average of four rows, was non-significant. Approximately, 318 seeds were discharged in 10 revolutions of the ground wheel as indicated by the laboratory test. The maximum deviation of seed discharge of any row from the average was less than 5 per cent. All the deviations were within the range of 7 per cent as set by the Indian standards. The average draft requirement of $378 \mathrm{kgf}$ was recorded for the planter using double tractor method of draft measurement.

\section{Field capacity, field efficiency and field machine index}

An average field capacity of 0.22 hah $^{-1}$ was obtained for continuous operation of carrot planter at an average speed of $1.56 \mathrm{kmph}$.A field efficiency of 76.36 per cent was observed which was in prescribed range of 65-75 per cent for planter. Major loss in the field efficiency was due to low forward speed of planter and turns at the head land. The average depth of seed placement of ten randomly selected observations was $2.1 \mathrm{~cm}$ and seeds were placed in the range of $1.65-2.4 \mathrm{~cm}$ depth. The field machine index was recorded as high as 79.75 per cent. This was due to the rectangular size of the test plot and less turning time at the head land.

\section{Average spacing, performance indices and plant population}

The average plant spacing for seed $S_{1}, S_{2}$ and $\mathrm{S}_{3}$ were $4.5 \mathrm{~cm}, 5.1 \mathrm{~cm}$ and $5 \mathrm{~cm}$ against the seed spacing of $4.8 \mathrm{~cm}, 5.1 \mathrm{~cm}$ and $5.3 \mathrm{~cm}$, respectively. The optimum plant population per meter length of bed was 72 for biogas slurry coated seed $S_{2}$ against theoretical plant population of 80 plants per meter length of bed. The coefficient of variation was less than 5 per cent. The higher number of plants over meter length of bed was 82.34 for uncoated 
seed $S_{1}$ against the theoretical 80 plants over that length. The lower and higher values of miss index were $8.57 \%$ and $15.71 \%$ for Thirame coated $\mathrm{S}_{3}$ and uncoated seed $\mathrm{S}_{1}$ respectively. The coefficients of variation of miss index for $S_{2}, S_{3}$ were less than 5 per cent. The best quality of planting (82.86 per cent quality of feed index) was observed in case of Thirame coated seed $S_{3}$ with coefficient of variation of 3.2 per cent. The higher multiple index was $15 \%$ observed in case of $S_{1}$, but the least value of multiple index was $8.57 \%$ in case of $S_{3}$. The higher value of precision was $17.42 \%$ for biogas slurry coated seed $S_{2}$, followed by $16.82 \%$ for Thirame coated seed $\mathrm{S}_{3}$.

\section{Average root dimensions and carrot yield}

The carrots were harvested using single row mechanical harvester. The average root dimensions such as, root length and diameter of 20 randomly selected carrots were recorded for all the treatments as shown in Table 3. Among the treatments, highest root length and diameter were recorded for treatment $\mathrm{S}_{2}$ $(21.92 \mathrm{~cm}$ and $3.37 \mathrm{~cm})$ followed by treatment $\mathrm{S}_{1}(17.61 \mathrm{~cm}$ and $2.95 \mathrm{~cm})$ with the coefficients of variation of 12.1 per cent and 9.9 per cent, respectively. The lowest root dimensions were recorded for treatment $S_{3}(15.71 \mathrm{~cm}$ and $2.5 \mathrm{~cm}$ ) with the coefficients of variation of 8.3 $\%$ and $15.9 \%$, respectively. The t-test showed significant difference in both length and diameter of carrot roots between all the treatments with 5 per cent level of significance. The yield was recorded for all treatments and presented descriptive statistics in the Table 2. The highest yield was observed for treatment $S_{2}$ (20.14 tons/ha), followed by treatment $S_{1}$ (17.69 tons $\left./ \mathrm{ha}\right)$. Yields for treatment $S_{2}$ varied significantly with the treatments $S_{1}$ and $S_{3}$.

Fig.1 Coated carrot seeds

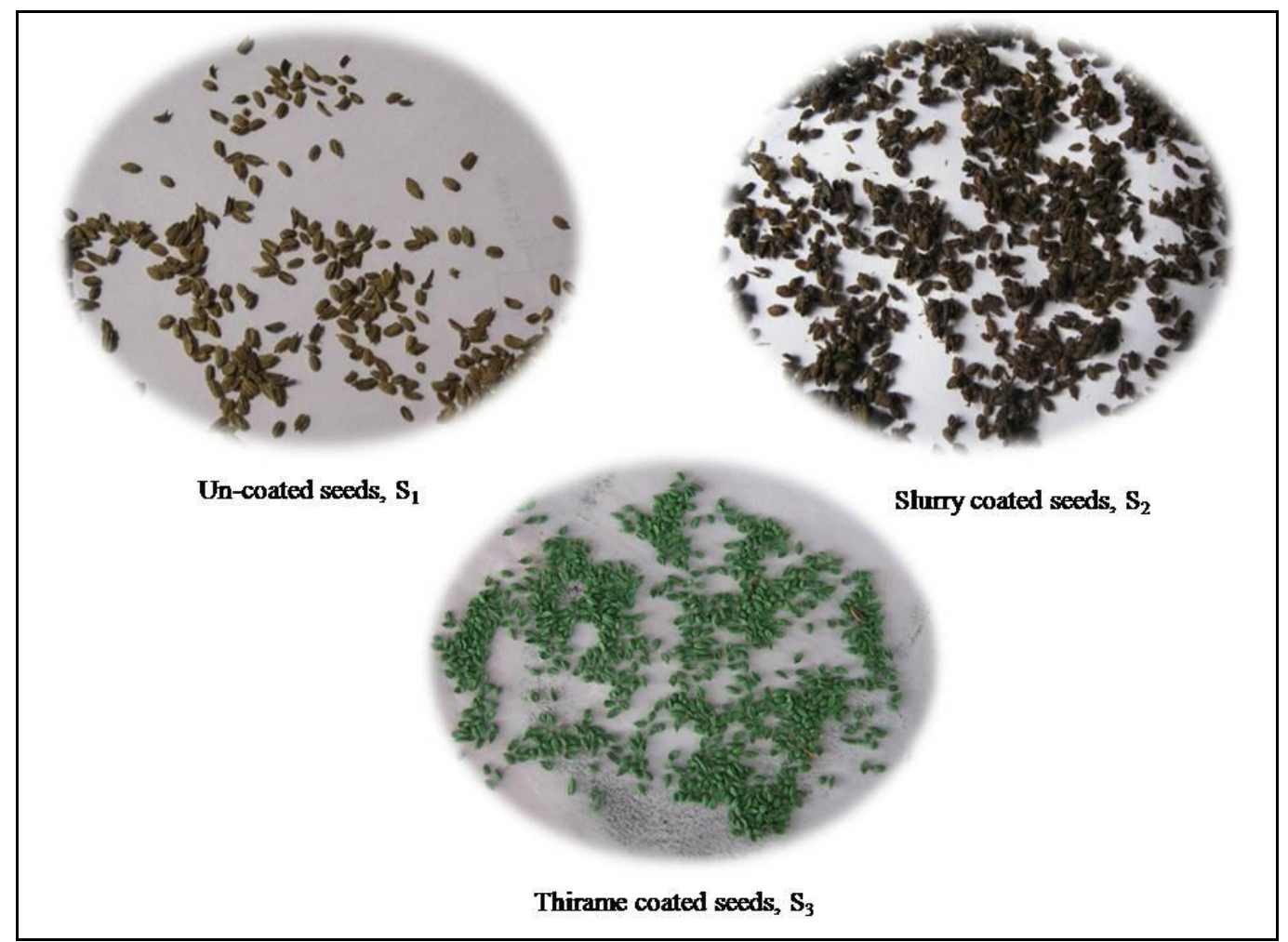


Fig.2 (a) Seed metering plate, and (b) prototype planter
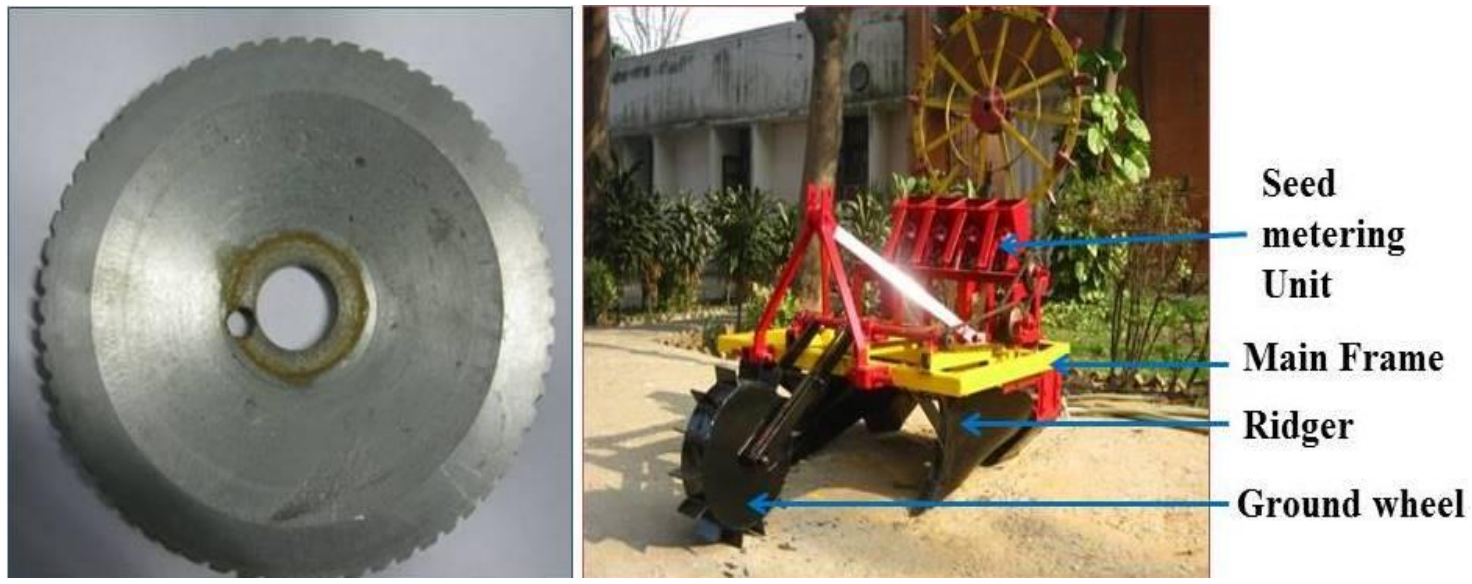

Fig.3 Conceptual diagram of mechanical carrot planter

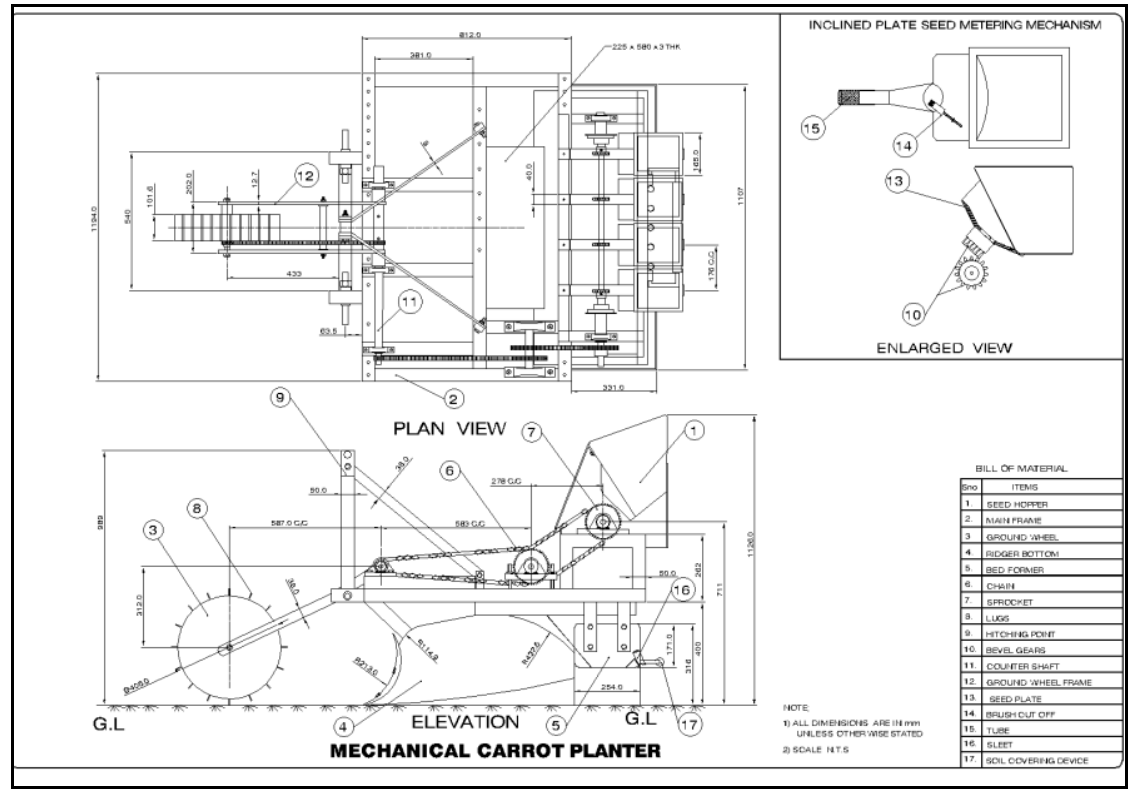

Table.1 Field performance data of carrot planter

\begin{tabular}{|c|l|c|}
\hline S. No & Performance parameters & Values \\
\hline 1 & Average depth of placement, cm & 2.1 \\
\hline 2 & Forward speed, kmph & 1.5 \\
\hline 3 & Average draft, kgf & 378 \\
\hline 4 & Average fuel consumption, $1 / \mathrm{h}$ & 4.2 \\
\hline $\mathbf{6}$ & Average field capacity, ha/h & 0.22 \\
\hline $\mathbf{7}$ & Average field efficiency, per cent & 76.36 \\
\hline $\mathbf{8}$ & Average field machine index, per cent & 79.39 \\
\hline
\end{tabular}


Table. 2 Performance of seed metering mechanism of planterin actual field conditions

\begin{tabular}{|c|c|c|c|c|}
\hline \multirow[t]{2}{*}{ S. No } & \multirow[t]{2}{*}{ Particulars } & \multicolumn{3}{|c|}{ Seed coat treatments } \\
\hline & & $\mathbf{S}_{1}$ & $\mathbf{S}_{\mathbf{2}}$ & $\mathbf{S}_{3}$ \\
\hline \multirow[t]{3}{*}{1} & Average plant spacing, $\mathrm{cm}$ & 4.5 & 5.07 & 5.2 \\
\hline & S.D & 0.61 & 0.38 & 0.33 \\
\hline & C.V, \% & 13.5 & 7.7 & 4.7 \\
\hline \multirow[t]{3}{*}{2} & Miss index, $\%$ & 15.71 & 9.29 & 8.57 \\
\hline & S.D & 5.34 & 1.89 & 2.44 \\
\hline & C.V, $\%$ & 0.34 & 0.24 & 0.28 \\
\hline \multirow[t]{3}{*}{3} & Multiple index, $\%$ & 15.71 & 10.71 & 8.57 \\
\hline & S.D & 0.34 & 4.49 & 2.44 \\
\hline & C.V, \% & 0.43 & 0.42 & 0.28 \\
\hline \multirow[t]{3}{*}{4} & Quality of feed index, \% & 67.14 & 80 & 82.86 \\
\hline & S.D & 7.32 & 5 & 2.67 \\
\hline & C.V, \% & 11.2 & 13.6 & 3.5 \\
\hline \multirow[t]{3}{*}{5} & Plant population per $\mathrm{m}$ length of bed & 82 & 72 & 63 \\
\hline & S.D & 1.19 & 0.78 & 0.59 \\
\hline & C.V,$\%$ & 7.18 & 3.04 & 1.76 \\
\hline
\end{tabular}

Note: $\mathrm{S}_{1}$-Uncoated carrot seeds; $\mathrm{S}_{2}$-Biogas slurry coated carrot seeds; $\mathrm{S}_{3}$-Thirame coated carrot seeds

Table.3 Comparison of planter performance with manual planting

\begin{tabular}{c|l|c|c|}
$\begin{array}{c}\text { S. } \\
\text { No }\end{array}$ & Performance parameters & \multicolumn{2}{|c|}{ Planting methods } \\
\hline $\mathbf{1}$ & Average plant spacing, cm & Mechanical & Manual \\
\hline $\mathbf{2}$ & Average Root length of carrot, cm & 18.91 & 5.4 \\
\hline $\mathbf{3}$ & Average root diameter of carrot, cm & 2.94 & 16.53 \\
\hline $\mathbf{4}$ & Average yield of carrots, tons/ha & 17 & 2.45 \\
\hline $\mathbf{5}$ & Cost of operation, Rs./ha & 1441 & 14.62 \\
\hline
\end{tabular}

Table.4 Independent Samples Test for carrot yield in treatments $S_{1}, S_{2}$ and $S_{3}$

\begin{tabular}{|c|c|c|c|c|}
\hline Treatments & \multicolumn{4}{|c|}{ t-test for Equality of Means } \\
& t-value & df & Sig (2-tailed) & Std. Error Difference \\
\hline $\mathrm{S}_{1}-\mathrm{S}_{2}$ & -2.94 & 12 & $0.01^{*}$ & 1.32 \\
\hline $\mathrm{S}_{2}-\mathrm{S}_{3}$ & 4.12 & 12 & $0.00^{*}$ & 1.34 \\
\hline $\mathrm{S}_{1}-\mathrm{S}_{3}$ & 1.28 & 12 & 0.22 & 1.28 \\
\hline
\end{tabular}

Note: $\mathrm{S}_{1}$-Uncoated carrot seeds; $\mathrm{S}_{2}$-Biogas slurry coated carrot seeds; $\mathrm{S}_{3}$-Thirame coated carrot seeds *Difference is significant at 5 per cent level

The mechanical carrot planter recorded minimum draft of $378 \mathrm{kgf}$ during the operation of planter, this was due to the lesser operating width of planter and forward speed. The average depth of seed placement was observed as $2.03 \mathrm{~cm}$, against the 
recommended depth of $2.5 \mathrm{~cm}$, this was due to the variability of clod size in the field. An average field capacity of $0.22 \mathrm{ha} / \mathrm{h}$ was obtained for continuous operation of carrot planter at an average speed of $1.56 \mathrm{kmph}$. A field efficiency of 76.36 per cent was obtained. The field machine index was more $(79.39 \%)$, this was due to the rectangular size of test plot and less turning at the head land. After the germination, the average plant spacings were $4.51 \mathrm{~cm}, 5.02 \mathrm{~cm}$ and $5.21 \mathrm{~cm}$ for $S_{1}, S_{2}$ and $S_{3}$ respectively, against the seed spacing of $5 \mathrm{~cm}$. Among all the treatments, minimum CV (4.7) and standard deviation (0.33) of average plant spacing were recorded for treatment $\mathrm{S}_{3}$ (Table 1). The multiple and missing indices both were large $(15.71 \%)$ for the treatment $S_{1}$. For the treatment $S_{3}$, the quality of feed index was higher $(82.86 \%)$ with the coefficient of variation $(3.5 \%)$ and standard deviation (2.67). The optimum plant population per meter length of bed was 72 for biogas slurry coated seed $S_{2}$ against theoretical plant population of 80 plants per meter length of bed. The plant population was more (82) for $S_{1}$, this was due to the more multiple seeds dropped during planting. The higher carrot root dimensions were observed for treatment $\mathrm{S}_{2}(21.92 \mathrm{~cm}$ and $3.37 \mathrm{~cm})$ as $\mathrm{t}$ test showed significant difference between all treatments (Table 4). The higher root dimensions resulted in high yields of carrots. The higher yield was 20.14 tons/ha for $S_{2}$ followed by 14.69 tons/ha for treatment $S_{1}$ (Table 3). There was a significant difference in the yield between the treatments $S_{1}$, and $S_{2}$, $\mathrm{S}_{2}$ and $\mathrm{S}_{3}$ with the $5 \%$ level. The highest yield was observed for treatment $S_{2}(20.14$ tons/ha), which was due to optimum plant population in treatment $S_{2}$ (72 against 80 plants).

Laboratory calibration of prototype planter for row to row uniformity showed a variation of only $4.6 \%$ within four rows. Mean draft requirement of planter was $378 \mathrm{kgf}$, with the fuel consumption of $4.2 \mathrm{l} / \mathrm{h}$ and field capacity of 0.22 ha/hour. Average depth of seed placement in field test of prototype planter was $2 \mathrm{~cm}$, which was in close proximity with the recommended depth of $1.65-2.5 \mathrm{~cm}$. Highest germination was obtained in treatment $\mathrm{S}_{2}(80 \%)$ and it was due to the slurry coating to the seed, which enhanced the direct nutrient availability to the seeds.

The optimum plant population per meter length of bed was 72 under treatment $\mathrm{S}_{2}$ against theoretical plant population of 80 plants, which resulted in higher yield of 20.14tonnes/hectare. The highest carrot root dimensions viz. length and diameter were recorded for treatment $S_{2}(21.92 \mathrm{~cm}$ and $3.37 \mathrm{~cm})$ as t-test showed significant difference between all treatments. The cost of operation of single row carrot planter was Rs.1441/ha and that of manual planting was Rs.3125/ha. This shows that, the adoption of this technology could help reduce cost of operation by 53.88 per cent. The developed prototype had break even points at $122 \mathrm{~h} /$ year with the payback period of 3.71 years. The two row mechanical raised bed carrot planter can perform better with increased capacity.

\section{References}

Bakhtiari, M. R and Loghavi, M., 2009. Development and Evaluation of an Innovative Garlic Clove Precision Planter. J. Agric. Sci. Technology, 11: 125-136.

Bracy, R. P., Parish, R. L and McCoy Joe, E.1999. Precision seeder uniformity varies with theoretical spacing. Horticultural Technology, 9(1): 47-50.

Kamaraj, P and Kathirvel, K. 2008. Development and evaluation of tractor operated belt type cotton planter. Journal of Agricultural Engineering, 45(1):69-72. 
Kowalczuk and Zarajczyk. 2005. Quality assessment of carrot seeding using precision belt seeder S011 ALEX. TEKA Kom. Mot. Energy, 6:41-45.

National Horticulture Board (Database) 2016. National Horticulture Board, Ministry of Agriculture, Government of India, Gurgaon, 160pp

Robert, J. Orath., Scott, R. M., Steven, Gand Michael T. 2009. Evaluation of a mechanical seed planter for transplanting Zosteramarina (eelgrass) seeds. Aquatic Botany, 90:204-208.

Shiddanagouda Yadachi, Indra Mani, Kalra, M. S., Adarsh Kumar and Sahoo, P. K. 2013. Development and Evaluation of Inclined Plate Metering Mechanism for Carrot Seed. Journal of Agricultural Engineering, 50 (2): 10-16.
Shiddanagouda Yadachi, Indra Mani, Mallikarjun Reddy and Kiran Nagajjanavar. 2012. Development of Seed Coating Technology for Carrot Seed. Environment \& Ecology, 30 (3A): 798 -801

Shiddanagouda Yadachi, Indra Mani and Kiran Nagajjanavar. 2014. Influence of Seed Coat Treatments on Seedling Emergence of Carrot (Daucus carota L.). International Journal of Current Microbiology Applied Science, 3(10): 1003-1007

Shiddanagouda Yadachi, Indra Mani, Kalra, M.S., Lande Satish and Cini Varghese. 2014. Effect of coatings on physical and engineering properties of carrots seeds in relation to planter design. Agricultural Mechanization in Asia, Africa and Latin America, 45 (3):64-68

\section{How to cite this article:}

Shiddanagouda Yadachi and Indra Mani. 2018. Design and Evaluation of Tractor Operated Raised Bed Mechanical Carrot Planter. Int.J.Curr.Microbiol.App.Sci. 7(09): 2213-2220. doi: https://doi.org/10.20546/ijcmas.2018.709.273 